\title{
Global Annual Final AC Yield Comparison between HCPV and c-Si PV
}

\author{
Juan Pablo Ferrer-Rodríguez, Pedro Pérez-Higueras, \\ Florencia Almonacid, and Eduardo F. Fernández
} Center of Advanced Studies in Energy and Environment (CEAEMA) IDEA Research Group, University of Jaén,
Campus Lagunillas, 23071 Jaén, Spain

Correspondence should be addressed to Juan Pablo Ferrer-Rodríguez; jferrer@ujaen.es

Received 30 June 2015; Revised 16 September 2015; Accepted 27 September 2015

Academic Editor: Thomas Vandervelde

Copyright (C) 2015 Juan Pablo Ferrer-Rodríguez et al. This is an open access article distributed under the Creative Commons Attribution License, which permits unrestricted use, distribution, and reproduction in any medium, provided the original work is properly cited.

A worldwide comparison of the annual yield between conventional c-Si photovoltaic (PV) technology and high concentrated photovoltaic (HCPV) technology is presented. The idea of this paper is to find the most appropriate locations for HCPV systems in terms of the annual energy produced when comparing to fixed tilt PV systems and two-axis oriented PY systems. For estimating the annual energy generation, the method of the Performance Ratio is used. For some locations with high annual direct normal irradiation values, which are distributed around the world, HCPV systems are found to be more advantageous than fixed tilt PV systems. World maps showing this comparison are presented.

\section{Introduction and Description of the Technology}

In this paper, we analyze the energy produced by three different kinds of photovoltaic plants: high concentration HCPV systems equipped with high efficiency multijunction solar cells (MJ) on a two-axis tracker, c-Si latitude tilt inclined fixed panels oriented to the south (in the Northern Hemisphere) and oriented to the north (in the Southern Hemisphere), and c-Si panels two-axis oriented. We also compare the energy produced by these HCPV systems with both kinds of $\mathrm{c}-\mathrm{Si}$ systems mentioned above. For all the cases, we only analyze the annual AC energy produced by grid-connected systems. The inputs for these calculations are (a) annual irradiation data from the NASA database and (b) Performance Ratio values from real PV and HCPV power plants.

Conventional c-Si photovoltaic (PV) technology is nowadays worldwide used for harvesting solar energy into electricity with a cumulative installed capacity of around $180 \mathrm{GW}$ in the year 2014, mostly grid-connected [1]. For fixed PV systems, the optimum tilt angle has been studied, being the simplest rule of inclining the panels according to the latitude for areas between $45^{\circ} \mathrm{S}$ and $45^{\circ} \mathrm{N}$ [2]. The annual input energy for fixed tilt c-Si PV systems is the global irradiation on a fixed tilt plane, $H_{A}\left[\mathrm{~kW} \cdot \mathrm{h} / \mathrm{m}^{2} \cdot\right.$ year], and for c-Si PV twoaxis tracking systems is the global normal irradiation, $H_{2 X, A}$ $\left[\mathrm{kW} \cdot \mathrm{h} / \mathrm{m}^{2} \cdot\right.$ year $]$.

High concentrator photovoltaic (HCPV) systems are intended to decrease the cost of the photovoltaic electricity generation through the reduction of the use of semiconductor material which is substituted by sunlight concentrating optical devices made of cheaper common materials (glass, plastic, etc.) [3].

HCPV systems are usually equipped with high efficiency III-V triple-junction solar cells. Each of these subcells is responsible for the photocurrent generation corresponding to different wavelength ranges of the solar spectrum, which are determined by the energy band gap of each subcell. Hence, the efficiency of a multijunction (MJ) solar cell is higher than that for a cell used in conventional c-Si PV modules because, among other reasons, $\mathrm{MJ}$ solar cells utilize a broader total wavelength range for the energy conversion $[4,5]$. Moreover, MJ solar cells have a higher potential of efficiency ratio than conventional solar cells of c-Si PV modules that is given by the thermodynamic limit, which grows with the number of junctions of the MJ solar cell [6]. As an example, considering 
a HCPV module of $1000 x$ concentration ratio of an area of $1 \mathrm{~m}^{2}$, the total area of MJ solar cell would be only $10 \mathrm{~cm}^{2}$, which can be a square cell of less than $3.2 \mathrm{~cm}$ side. For achieving such concentrating ratios, efficient and optimized optical designs that concentrate direct sunrays have to be implemented. Since HCPV systems concentrate direct sunrays, it is preferable to install them in those regions with the highest annual direct irradiance levels $\left(\mathrm{DNI}_{A}\right.$, measured in $\mathrm{kW} \cdot \mathrm{h} / \mathrm{m}^{2}$ ). High performance optical systems in HCPV modules usually collect and concentrate direct sunrays onto the small solar cell in two optical stages that are implemented by the elements often known as POE (primary optical element) and SOE (secondary optical element). Fresnel lenses are usual POE elements and concentrate direct sunlight whereas a wide variety of prisms are often used as SOE in order to homogenize the irradiance distribution over the solar cell as well as to increase the acceptance angle of the system, which decreases as the concentration ratio increases [7]. HCPV modules are typically mounted on a high accuracy pedestal two-axis tracker in order to align the optics with the sunrays. The higher the acceptance angle of the concentrating optics of the HCPV module is, the lower the accuracy requirements of the tracker system are $[8,9]$.

\section{Calculation of the Annual Yield for Grid-Connected Systems}

The estimation of the energy yield of grid-connected photovoltaic systems depends on the atmospheric parameters, on its location, on the electrical characteristics of the photovoltaic generator, and on its angle of inclination and orientation. Moreover, it is necessary to consider a series of losses referred to the generator to calculate the energy generated, as it has been pointed in some studies [10]. Particularly the dependency of the electrical efficiency of the generator with the temperature [11], mismatch effects, tolerance losses, losses due to soiling, and so forth have to be considered. So, the energy yield estimation methods for grid-connected systems are usually based on the experimental values of the parameters involved in the mathematical expressions used.

There are different methods [12] to calculate the energy generated by a photovoltaic grid-connected system. The method based on the Performance Ratio (PR) is one of the most used methods. The IEC standard 61724 [13] defines that the annual electricity generated by a conventional fixed PV system with panels optimally inclined over the horizontal and permanently oriented southwards can be estimated using the next equation:

$$
Y_{\mathrm{PV}}=\operatorname{PR} \frac{H_{\mathrm{opt} A}}{G_{\mathrm{STC}}},
$$

where $Y_{\mathrm{PV}}$ is the final annual AC energy yield in a conventional fixed grid-connected system $\left[\mathrm{kW} \cdot \mathrm{h} / \mathrm{kW}_{\mathrm{p}} \cdot\right.$ year $], H_{\mathrm{opt} A}$ is the annual global irradiation on optimally inclined plane $\left[\mathrm{kW} \cdot \mathrm{h} / \mathrm{m}^{2} \cdot\right.$ year] , and $G_{\mathrm{STC}}$ is the global irradiance in standard test conditions $\left[1 \mathrm{~kW} / \mathrm{m}^{2}\right]$.

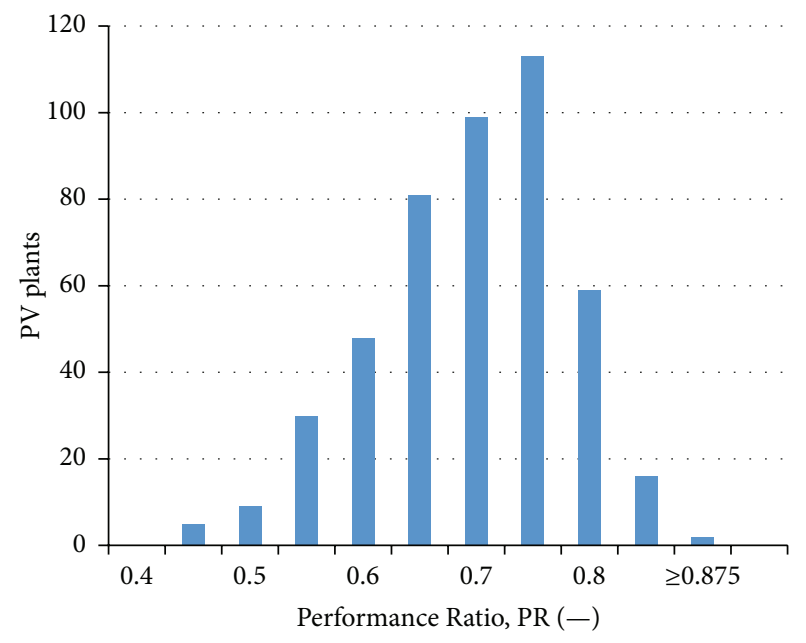

FIgURE 1: Histogram of the annual Performance Ratio for PV systems [15].

The Performance Ratio (PR) coefficient (nondimensional) describes the relation between the final energy output real and theoretical one of a photovoltaic installation. Therefore, PR is a measure of the quality of a photovoltaic installation and shows the proportion of energy that is available at the output after subtracting the energy losses in the system. The higher the PR is, the more efficient the gridconnected PV installation is. It is impossible to achieve a PR = $100 \%$ because of the unavoidable losses. A high efficiency grid-connected PV power plant can achieve a value of $\mathrm{PR}=$ 80\% [14]. The International Energy Agency [15] has analyzed the performance of different PV systems and it concludes that the range of $\mathrm{PR}$ values is quite wide, from a minimum of $40 \%$ to a maximum of $85 \%$ (see Figure 1). Specifically, for grid-connected systems installed since the year 1996 the average value is $74 \%$. The $\mathrm{PR}$ value in a conventional fixed grid-connected PV system usually ranges from $70 \%$ to $80 \%$. Based on the experience in this kind of systems [16-20], we have used a value of $78 \%$ for grid-connected PV systems of high efficiency and a value of $75 \%$ for standard systems. In addition, a value of $\mathrm{PR}=78 \%$ has been also taken for c-Si PV two-axis grid-connected systems in this work based on the analyses previously cited.

The annual electricity generated by a HCPV system can be estimated using the following equation:

$$
Y_{\mathrm{HCPV}}=\mathrm{PR} \frac{\mathrm{DNI}_{A}}{\mathrm{DNI}_{\mathrm{STC}}},
$$

where $Y_{\mathrm{HCPV}}$ is the final $\mathrm{AC}$ annual energy yield in a $\mathrm{HCPV}$ system $\left[\mathrm{kW} \cdot \mathrm{h} / \mathrm{kW}_{\mathrm{p}} \cdot\right.$ year], $\mathrm{DNI}_{A}$ is the annual direct normal irradiation $\left[\mathrm{kW} \cdot \mathrm{h} / \mathrm{m}^{2} \cdot\right.$ year $]$, and $\mathrm{DNI}_{\mathrm{STC}}$ is the direct normal irradiance at standard test condition $\left[1 \mathrm{~kW} / \mathrm{m}^{2}\right]$. The definition of the final AC annual energy yield for c-Si PV twoaxis tracking systems can be expressed as

$$
Y_{2 X \mathrm{PV}}=\mathrm{PR} \frac{H_{2 X A}}{G_{\text {STC }}},
$$


TAble 1: Performance Ratio (PR) for some HCPV power plants [21].

\begin{tabular}{lccc}
\hline Company/location & $\mathrm{DNI}_{A}\left(\mathrm{~kW} \cdot \mathrm{h} / \mathrm{m}^{2} \cdot\right.$ year $)$ & $Y_{\mathrm{HCPV}}\left(\mathrm{kW} \cdot \mathrm{h} / \mathrm{kW} \mathrm{p}_{\mathrm{p}} \cdot \mathrm{year}\right)$ & $\mathrm{PR}(\%)$ \\
\hline Soitec/Touwsrivier & 2447 & 1878 & $76-81$ \\
SolFocus/Puertollano (ISFOC) & 1861 & 1914 & 88.7 \\
Magpower/Portugal & 1978 & 2113 & 91 \\
Semprius/NREL & 2446 & 2079 & 85 \\
Solar Systems/Hermannsburg & 2464 & 2104 & 85.4 \\
\hline
\end{tabular}

where the annual global normal irradiation on a plane two-axis oriented, $H_{2 X A}\left[\mathrm{~kW} \cdot \mathrm{h} / \mathrm{m}^{2} \cdot\right.$ year $]$, can be expressed besides as

$$
H_{2 X_{A}}=\mathrm{DNI}_{A}+\text { Diffuse }_{A} \text {, }
$$

where Diffuse $_{A}$ is the annual diffuse radiation $[\mathrm{kW} \cdot \mathrm{h} /$ $\mathrm{m}^{2}$.year].

The value of PR in a typical HCPV system ranges from $76 \%$ to $91 \%$ in general as shown in Table 1 and is analyzed in some examples: case of SolFocus [22], case of Amonix [23], case of Daido Steel study concerning the spectral influence on the Performance Ratio [24], and case of Semprius [25]. Based on the analysis of these data and arguing similarly to the cSi PV case, we have used a value of $82 \%$ for high efficiency systems and a value of $80 \%$ for standard systems.

The solar irradiation annual data used for the calculations were taken from the NASA database [26] and have a resolution of $1^{\circ}$ for latitude and longitude. Although $\mathrm{DNI}_{A}$ data were available, $H_{\text {opt A }}$ were not used for the calculations of this study. Instead of $H_{\text {opt } A}$, data of annual global irradiation on latitude tilt plane were used. The optimum inclination of the fixed PV panel does not match the latitude tilt angle, so a brief analysis of the error of this approximation is shown in the next section.

\section{Optimum Tilt Angle and Error Estimation}

In Figure 2, the optimum tilt angle for a fixed panel in the North Hemisphere oriented to the south as a function of the latitude for some different locations (around 30 locations) in Africa and Europa is shown. These optimum angle values are taken from the PVGIS [27]. The strait line represents the panel's tilt angles that coincide with the angle of latitude, that is, the tilt angles corresponding to the annual global irradiation on fixed PV panels data used in our study. We can distinguish three parts in the graph of Figure 2. For latitudes between $15^{\circ}$ and $35^{\circ}$ the latitude tilt angle is a good approximation to the optimum angle. For latitudes between $0^{\circ}$ and $15^{\circ}$ the optimum angle is few degrees higher than that of the latitude. For latitudes higher than $35^{\circ}$ the optimum angles are clearly lower (up to $10^{\circ}$ less) than the latitude angles. The highest deviation in terms of annual irradiance by taking the optimum tilt angle versus the latitude tilt angle is $30 \mathrm{~kW} \cdot \mathrm{h} / \mathrm{m}^{2} \cdot$ year for these 30 locations analyzed. Note that this is not an exhaustive analysis of this issue, since only around 30 locations have been considered in order to have an approach to the error of this approximation.

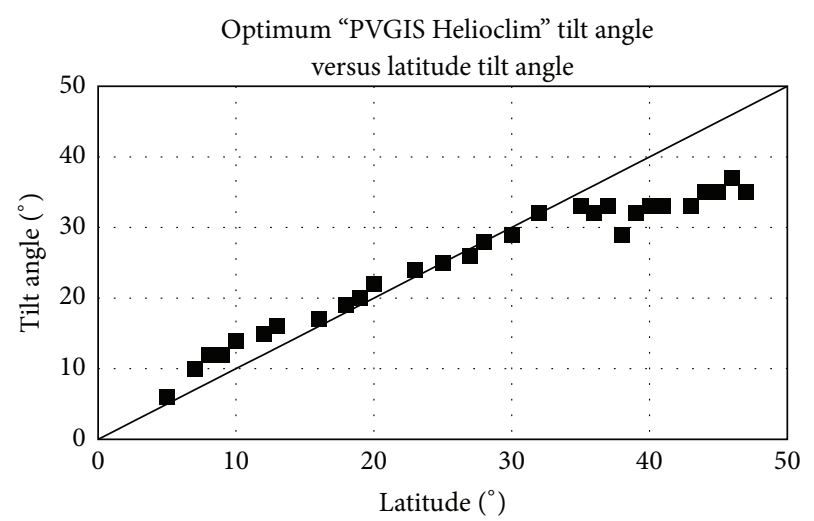

FIGURE 2: Optimum inclination angle for fixed PV panels in comparison with latitude tilt angle.

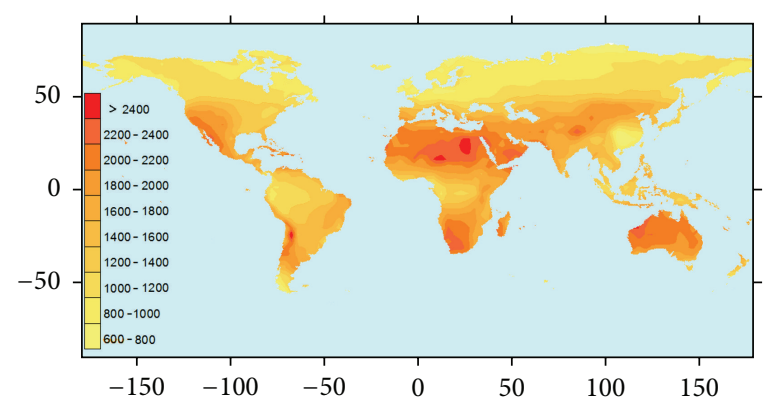

FIGURE 3: Map of global annual AC final yield, $Y_{\mathrm{HCPV}}$, measured in $\mathrm{kW} \cdot \mathrm{h} / \mathrm{kW}_{\mathrm{p}}$ for a HCPV power plant. A Performance Ratio (PR) of 0.82 was considered for the calculation.

The standard deviation for these data corresponds to around $8 \mathrm{~kW} \cdot \mathrm{h} / \mathrm{m}^{2} \cdot$ year, which corresponds to ca. $0.4 \%$ of relative standard deviation. Therefore we can conclude that this approximation is justified for the purpose of the study presented in this work.

\section{Calculation Results and Conclusions}

Figure 3 represents the global final AC annual yield of a $\mathrm{HCPV}$ system, $Y_{\mathrm{HCPV}}$, when considering a $\mathrm{PR}=0.82$. The values obtained are in the range of 600 to $2400 \mathrm{~kW} \cdot \mathrm{h} /$ $\mathrm{kW}_{\mathrm{p}}$.year. The regions with higher values of $Y_{\mathrm{HCPV}}$ are, obviously, those with higher values of $\mathrm{DNI}_{A}$, typically around $2400 \mathrm{~kW} \cdot \mathrm{h} / \mathrm{m}^{2} \cdot$ year. They may correspond to areas with very much fewer clouds, typically arid zones. 
Africa is the continent with overall higher values of $Y_{\mathrm{HCPV}}$ and the more remarkable regions (with maximums of $2400 \mathrm{~kW} \cdot \mathrm{h} / \mathrm{m}^{2} \cdot$ year) in this continent are

(i) Libyan Desert,

(ii) Ténéré Desert (south central Sahara),

(iii) Sahara Desert in general.

Another African desert region with high values is the Namib Desert, with values of around $2300 \mathrm{~kW} \cdot \mathrm{h} / \mathrm{m}^{2} \cdot$ year. The areas near to those deserts cited above are also of interest for $\mathrm{HCPV}$ due to their relative high values of $Y_{\mathrm{HCPV}}$. The Arabian Peninsula also shows relative high values of $Y_{\mathrm{HCPV}}$ that are in the range of $1800-2200 \mathrm{~kW} \cdot \mathrm{h} / \mathrm{m}^{2} \cdot$ year. In the Mediterranean zone the HCPV yield is around $1600 \mathrm{~kW} \cdot \mathrm{h} / \mathrm{m}^{2} \cdot$ year, representing the European highest yield values. Asiatic regions near the parallel $35^{\circ} \mathrm{N}$ at the west of the Gobi Desert and in the desert itself are also of interest for HCPV due to their relative high yield values. In Oceania, the northwest zone of Australia shows the highest values of HCPV yield, which are near to $2200 \mathrm{~kW} \cdot \mathrm{h} / \mathrm{m}^{2} \cdot$ year. In North America, the western regions of Mexico and southwestern USA, where there are some deserts, are the most preferable for HCPV, reaching yield values up to around $2200 \mathrm{~kW} \cdot \mathrm{h} / \mathrm{m}^{2} \cdot$ year. Cuba and some other Caribbean islands reach yields values of $2000 \mathrm{~kW} \cdot \mathrm{h} / \mathrm{m}^{2} \cdot$ year. In South America, The area of Atacama Desert and its surroundings shows very high yield values up to $2400 \mathrm{~kW} \cdot \mathrm{h} / \mathrm{m}^{2} \cdot$ year.

In Figure 4 the global final $\mathrm{AC}$ annual yield map for conventional c-Si PV inclined over the horizontal according to the latitude, $Y_{\mathrm{PV}}$, is shown. A value of $\mathrm{PR}=0.78$ was applied for this calculation. This map is similar to that for HCPV technology but with some differences. The maximum yield, $Y_{\mathrm{PV}}$, value is not higher than $2000 \mathrm{~kW} \cdot \mathrm{h} / \mathrm{m}^{2} \cdot$ year, less than in the case of $Y_{\mathrm{HCPV}}$. The regions with higher yield values are very similar to those of the $Y_{\mathrm{HCPV}}$ map (Figure 3) like, for example, in the case of all the deserts previously cited.

Moreover, the global final AC annual yield map for cSi two-axis tracking systems, $Y_{2 X \mathrm{PV}}$, is plotted in Figure 5, where a value of $P R=0.78$ was considered. In this case, the values are clearly higher than in the case of those of the map of Figure 3 ( $Y_{\mathrm{HCPV}}$ map) for all regions. This is an important conclusion that can be explained due to the fact that a c-Si PV two-axis tracking system utilizes not only the direct normal irradiation, which is the case of the HCPV systems, but also the diffuse radiation, Diff use . $_{\text {. }}$

The ratio $Y_{\mathrm{HCPV}} / Y_{\mathrm{PV}}$ is plotted for each location when considering $\mathrm{PR}_{\mathrm{HCPV}}=0.82$ and $\mathrm{PR}_{\mathrm{PV}}=0.75$ in Figure 6 . The green color denotes ratio values lower than 1 and red colors are for ratio values higher than 1 . The areas corresponding to latitudes much higher than $50^{\circ}$ in absolute value, which is near the polar circles and beyond, are not of interest due to their relative low levels of $Y_{\mathrm{HCPV}}$. This figure shows the more and the less preferable locations for a HCPV plant in terms of the electrical energy than can be produced in a year compared to a PV plant latitude tilt oriented.

For some regions, the energy produced by HCPV plants and PV plants latitude tilt oriented is quite similar. Those are

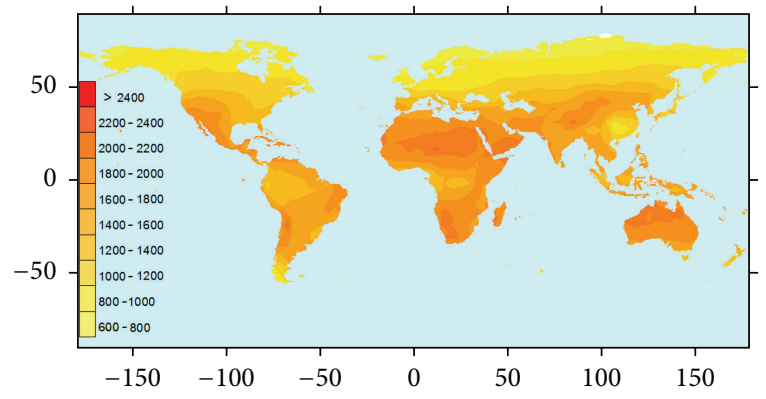

FIgURE 4: Map of global annual AC final yield, $Y_{\mathrm{PV}}$, measured in $\mathrm{kW} \cdot \mathrm{h} / \mathrm{kW}_{\mathrm{p}}$ for a conventional $\mathrm{c}$-Si PV power plant latitude tilt oriented. A Performance Ratio (PR) of 0.78 was considered for the calculation.

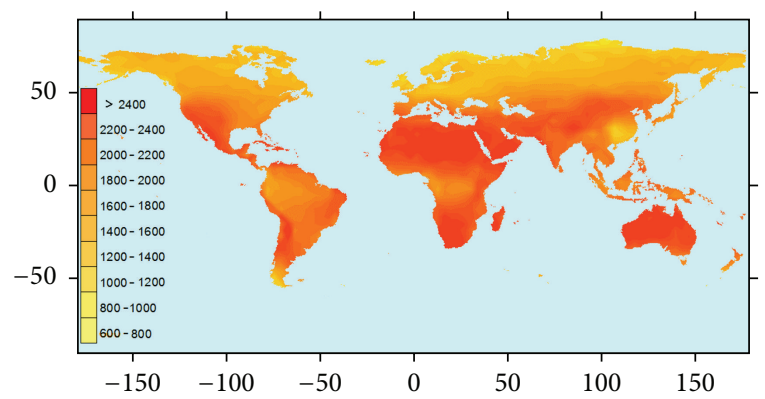

FIGURE 5: Map of global annual AC final yield, $Y_{2 X \text { PV }}$, measured in $\mathrm{kW} \cdot \mathrm{h} / \mathrm{kW}_{\mathrm{p}}$ for a conventional c-Si PV power plant two-axis oriented. A Performance Ratio (PR) of 0.78 was considered for the calculation.

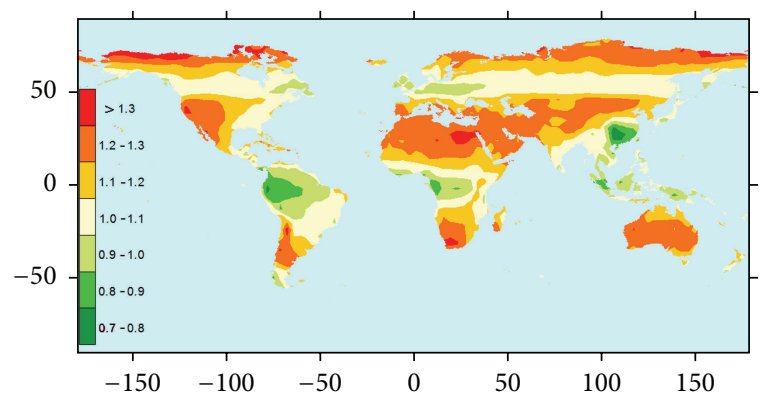

FIGURE 6: Ratio $Y_{\mathrm{HCPV}} / Y_{\mathrm{PV}}$ considering $\mathrm{PR}_{\mathrm{HCPV}}=0.82$ and $\mathrm{PR}_{\mathrm{PV}}=$ 0.75 .

the regions in which the ratio $Y_{\mathrm{HCPV}} / Y_{\mathrm{PV}}$ is in the range $0.9-$ 1.1. These regions correspond majorly to southeast of Brazil, eastern USA, equatorial zones in central Africa, southern India and southwestern China, and the surroundings to the parallel $+50^{\circ}$ north across Asia and America. The more interesting regions for locating a HCPV plant, taking into account its advantage for producing energy referred to a PV plant latitude tilt oriented, are the desert regions cited previously: deserts in California and surroundings (USA), Atacama (Chile), western Sahara and Namib (Africa), and western deserts in Australia. These desert zones correspond to ratio values of 1.3; that is, there the energy yield of a HCPV plant is $30 \%$ higher than for a PV one. The zones 
surrounding the cited deserts are also of high interest for HCPV installations compared to PV. There are also large extensions suitable for HCPV that achieve 1.2 ratio values like

(i) Sahara desert (central and western),

(ii) southwestern Africa,

(iii) Arabian Peninsula,

(iv) Mediterranean regions from the Iberian Peninsula to Israel,

(v) the area from Turkey to Pakistan and from Pakistan to Uzbekistan,

(vi) Mongolia and western China,

(vii) western USA and Mexico,

(viii) north Chile and middle Argentina,

(ix) Australia, excepting the northern and southern zones relative to the desert regions.

The less favorable regions for HCPV are also clearly visible in dark green in this map and correspond to ratio values of 0.7 ; that is, a PV plant would produce $30 \%$ more energy yearly than a HCPV one. These regions correspond to equatorial regions overall: in South America and in Africa, more seriously in the western areas for both cases, and in the southern Asiatic and Oceanic archipelagos. Also in eastern China the irradiance conditions are disadvantageous for HCPV. Northern Europe is also unfavorable for HCPV. These more disadvantageous regions for HCPV have in common high presence of humidity in the atmosphere in the form of clouds majorly, when averaging during a whole year in comparison to sunny regions.

A more restrictive case for HCPV technology is shown in Figure 7, in which the Performance Ratio is imposed to be $\mathrm{PR}_{\mathrm{HCPV}}=0.80$ and $\mathrm{PR}_{\mathrm{PV}}=0.78$. In fact, this is the same as analyzing the ratio $\mathrm{DNI}_{A} / H_{\text {opt } A}$, that is, the ratio between the usable energy for HCPV systems and c-Si PV systems, since the other terms in the definitions equations (1) and (2) have the same numerical value in this specific case. This map is very similar to the previous one (Figure 6). The main difference is that the ratio values are closer to 1 , which leads to the result that the usable energy for HCPV systems only deviates 30\% over that of PV systems in some deserts (Libya, Egypt, Namib, and Atacama). Nevertheless, there are wide regions in which the usable energy for HCPV systems is $20 \%$ higher than for c-Si PV systems.

Finally, the ratio $Y_{\mathrm{HCPV}} / Y_{2 X}$ PV comparing HCPV systems with c-Si PV two-axis systems is plotted in Figure 8. This ratio is $<1$ for all the regions since as explained before the incoming useful energy for a c-Si PV two-axis system is always greater than for HCPV systems because of the diffuse radiation that the $\mathrm{c}$-Si panels convert into electricity. From this map of Figure 8, it can be observed that the annual final AC yield is very similar for HCPV systems compared to that for cSi PV two-axis systems in some regions spread worldwide that correspond to the highest values of $Y_{\mathrm{HCPV}}$. However, the efficiency of HCPV systems is higher than that of c-Si systems, and this contributes to reduce costs. Bearing this in mind, this issue should be deeply analyzed in a future research

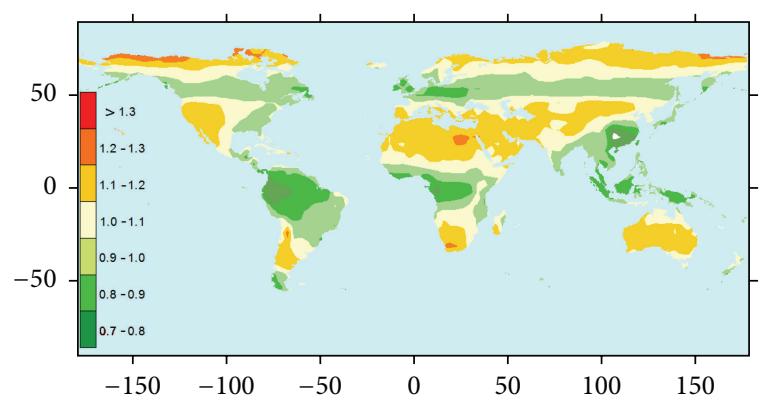

FIGURE 7: Ratio $Y_{\mathrm{HCPV}} / Y_{\mathrm{PV}}$ considering $\mathrm{PR}_{\mathrm{HCPV}}=0.80$ and $\mathrm{PR}_{\mathrm{PV}}=$ 0.78 .

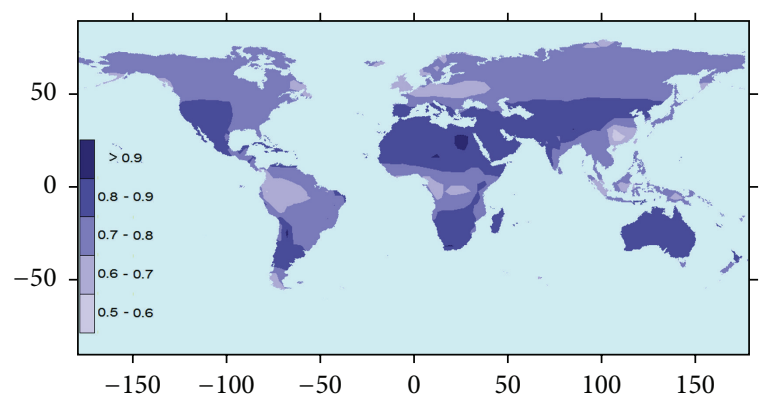

Figure 8: Ratio $Y_{\mathrm{HCPV}} / Y_{2 X \mathrm{PV}}$ considering $\mathrm{PR}_{\mathrm{HCPV}}=0.82$ and $\mathrm{PR}_{2 X \mathrm{PV}}=0.78$.

work in order to better select the best technology for each specific region.

Based on this analysis, it can be concluded that the use of HCPV, c-Si PV, or c-Si PV two-axis tracking technology depends on the region considered. There are regions worldwide in which the energy yield of HCPV technology is higher than in c-Si PV technology and vice versa. Moreover, the energy yield of HCPV systems is always lower than that of c-Si PV two-axis tracking systems; however, HCPV systems need less surface because of their higher efficiency and power density. For those reasons, the implementation of each specific technology has to be carefully analyzed for the area of interest.

\section{Conflict of Interests}

The authors declare that there is no conflict of interests regarding the publication of this paper.

\section{Acknowledgments}

This work is part of the Project ENE2013-45242-R supported by the Spanish Economy Ministry and by the European Regional Development Fund/Fondo Europeo de Desarrollo Regional (ERDF/FEDER).

\section{References}

[1] M. Brunisholz, "A snapshot of global PV markets-1992-2014," Report IEA-PVPS T1-26, 2015. 
[2] C. Breyer and J. Schmid, "Global distribution of optimal tilt angles for fixed tilted PV systems," in Proceedings of the 25th European Photovoltaic Solar Energy Conference and Exhibition, Valencia, Spain, September 2010.

[3] A. Luque, G. Sala, and I. Luque-Heredia, "Photovoltaic concentration at the onset of its commercial deployment," Progress in Photovoltaics: Research and Applications, vol. 14, no. 5, pp. 413428, 2006.

[4] H. Cotal, C. Fetzer, J. Boisvert et al., "III-V multijunction solar cells for concentrating photovoltaics," Energy and Environmental Science, vol. 2, no. 2, pp. 174-192, 2009.

[5] G. Zubi, J. L. Bernal-Agustín, and G. V. Fracastoro, "High concentration photovoltaic systems applying III-V cells," Renewable and Sustainable Energy Reviews, vol. 13, no. 9, pp. 2645-2652, 2009.

[6] G. Létay and A. W. Bett, "EtaOpt-a program for calculating limiting efficiency and optimum bandgap structure for multibandgap solar cells and TPV cells," in Proceedings of the 17th European Photovoltaic Solar Energy Conference, Munich, Germany, October 2001.

[7] M. Buljan, J. Mendes-Lopes, P. Benítez, and J. C. Miñano, "Recent trends in concentrated photovoltaics concentrators' architecture," Journal of Photonics for Energy, vol. 4, no. 1, Article ID 040994, 2014.

[8] E. Muñoz, P. G. Vidal, G. Nofuentes et al., "CPV standardization: an overview," Renewable and Sustainable Energy Reviews, vol. 14, no. 1, pp. 518-523, 2010.

[9] International Electrotechnical Commission, IEC 62108. Concentrator Photovoltaic (CPV) Modules and Assemblies-Design Qualification and Type Approval, ed. 1.0, International Electrotechnical Commission, Geneva, Switzerland, 2007.

[10] P. Rodrigo, C. Rus, F. Almonacid, P. J. Pérez-Higueras, and G. Almonacid, "A new method for estimating angular, spectral and low irradiance losses in photovoltaic systems using an artificial neural network model in combination with the Osterwald model," Solar Energy Materials and Solar Cells, vol. 96, no. 1, pp. 186-194, 2012.

[11] E. Skoplaki and J. A. Palyvos, "On the temperature dependence of photovoltaic module electrical performance: a review of efficiency/power correlations," Solar Energy, vol. 83, no. 5, pp. 614-624, 2009.

[12] C. Rus-Casas, J. D. Aguilar, P. Rodrigo, F. Almonacid, and P. J. Pérez-Higueras, "Classification of methods for annual energy harvesting calculations of photovoltaic generators," Energy Conversion and Management, vol. 78, pp. 527-536, 2014.

[13] International Electrotechnical Commission (IEC), IEC 61724: Photovoltaic System Performance Monitoring-Guidelines for Measurement, Data Exchange and Analysis, International Electrotechnical Commission, Geneva, Switzerland, 1st edition, 1998.

[14] SMA Solar Technology AG, "Performance ratio. Quality factor for the PV plant," Perfratio-UEN100810.

[15] L. Clavadetscher and T. Nordmann, "Cost and performance trends in grid-connected photovoltaic systems and case studies," Report IEA-PVPS T2-06, 2007.

[16] M. Súri, T. A. Huld, E. D. Dunlop, and H. A. Ossenbrink, "Potential of solar electricity generation in the European union member states and candidate countries," Solar Energy, vol. 81, no. 10, pp. 1295-1305, 2007.

[17] J. A. Ruiz-Arias, J. Terrados, P. Pérez-Higueras, D. PozoVázquez, and G. Almonacid, "Assessment of the renewable energies potential for intensive electricity production in the province of Jaén, southern Spain," Renewable and Sustainable Energy Reviews, vol. 16, no. 5, pp. 2994-3001, 2012.

[18] M. Drif, P. J. Pérez, J. Aguilera et al., "Univer Project. A grid connected photovoltaic system of $200 \mathrm{~kW}_{\mathrm{p}}$ at Jaén University. Overview and performance analysis," Solar Energy Mater Solar Cells, vol. 91, no. 8, pp. 670-683, 2007.

[19] S. J. Ransome, J. H. Wohlgemuth, and B. P. Solar, "kWh/kWp dependency on PV technology and balance of systems performance," in Proceedings of the 29th IEEE Photovoltaic Specialists Conference, pp. 1420-1423, May 2002.

[20] J. D. Mondol, Y. G. Yohanis, M. Smyth, and B. Norton, "Performance analysis of a grid-connected building integrated photovoltaic system," in Proceedings of the ISES Solar World Congress, Göteborg, Sweden, June 2003.

[21] D. Talavera, P. Pérez-Higueras, J. Ruíz-Arias, and E. Fernández, "Levelised cost of electricity in high concentrated photovoltaic grid connected systems: spatial analysis of Spain," Applied Energy, vol. 151, pp. 49-59, 2015.

[22] C. King, "Site data analysis of CPV plants," in Proceeding of the 35th IEEE Photovoltaic Specialists Conference (PVSC '10), pp. 3043-3047, Honolulu, Hawaii, USA, June 2010.

[23] S. Kenneth, "Analysis of five years of field performance of the Amonix high concentration PV system," in Proceedings of the Power-Gen Renewable Conference, 2006.

[24] H. Al Husna, N. Shibata, N. Sawano et al., "Impact of spectral irradiance distribution and temperature on the outdoor performance of concentrator photovoltaic system," AIP Conference Proceedings, vol. 1556, pp. 252-255, 2013.

[25] B. King, D. Riley, C. Hansen, M. Erdman, J. Gabriel, and K. Ghosal, "HCPV characterization: analysis of fielded system data," AIP Conference Proceedings, vol. 1616, pp. 276-279, 2014.

[26] NASA, "Surface meteorology and solar energy data information," 2015.

[27] European Commission, PVGIS: PV Potential Estimation Utility, Photovoltaic Geographical Information System, July 2015, http://re.jrc.ec.europa.eu/pvgis/apps4/pvest.php. 


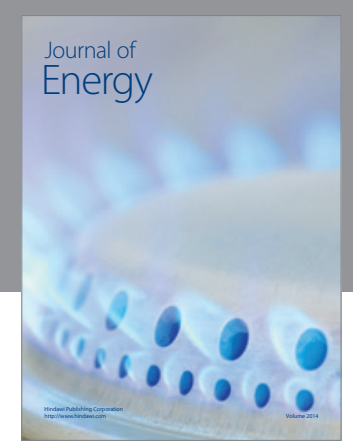

Journal of

Industrial Engineering
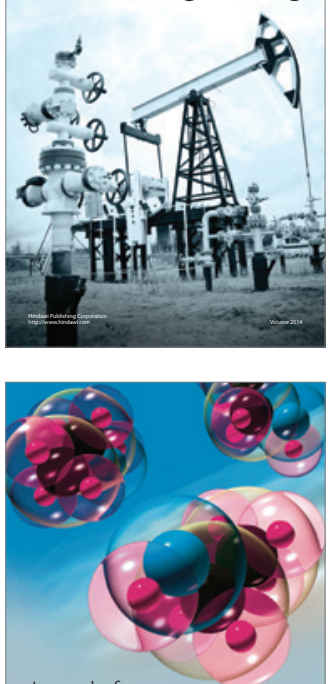

Fuels
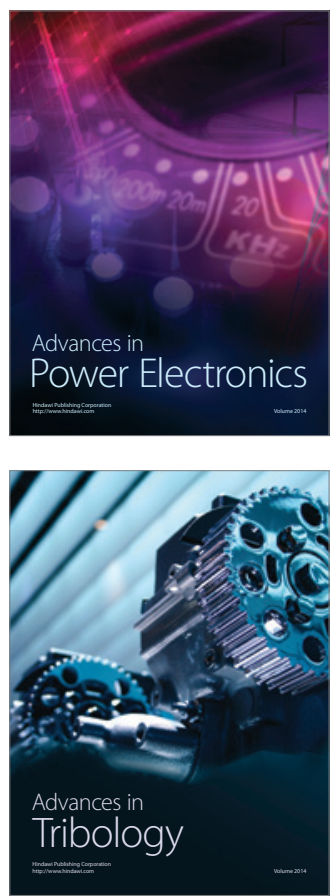

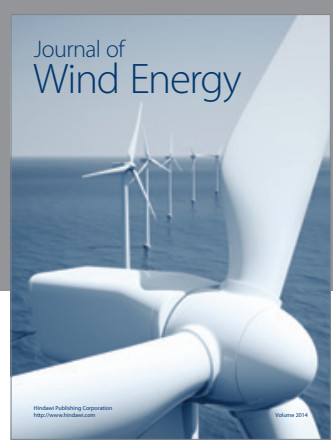

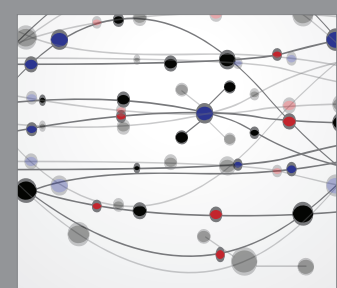

The Scientific World Journal

Submit your manuscripts at http://www.hindawi.com

Journal of

Structures
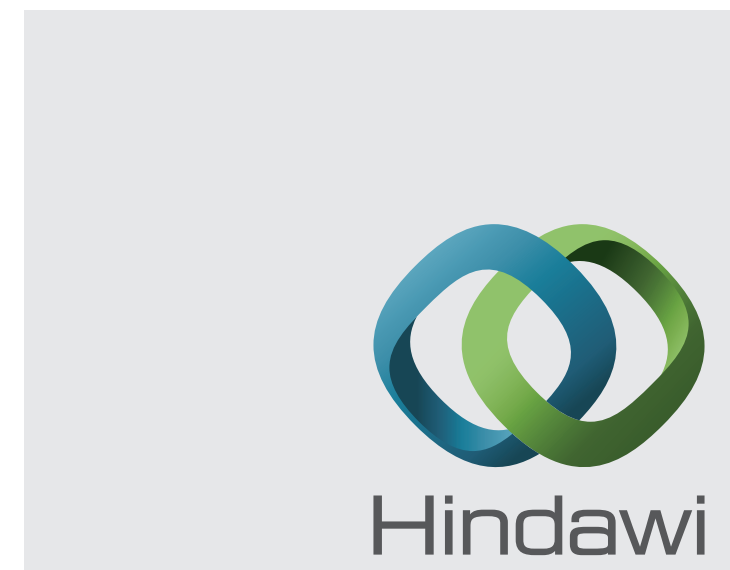

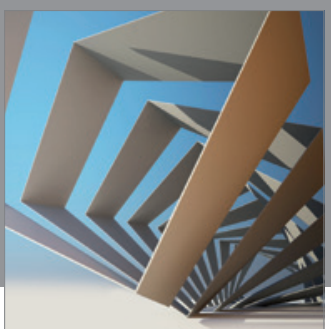

Rotating

Machinery
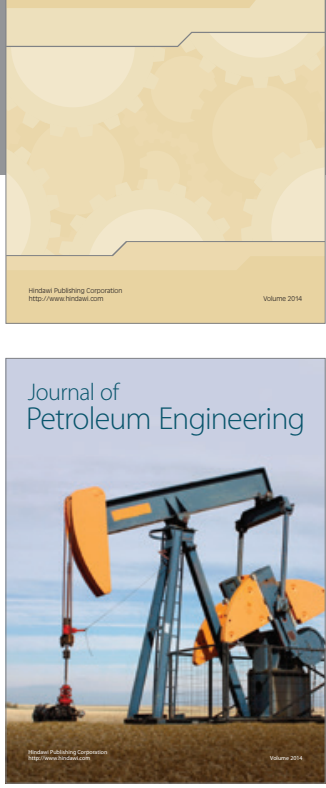

Journal of

Solar Energy
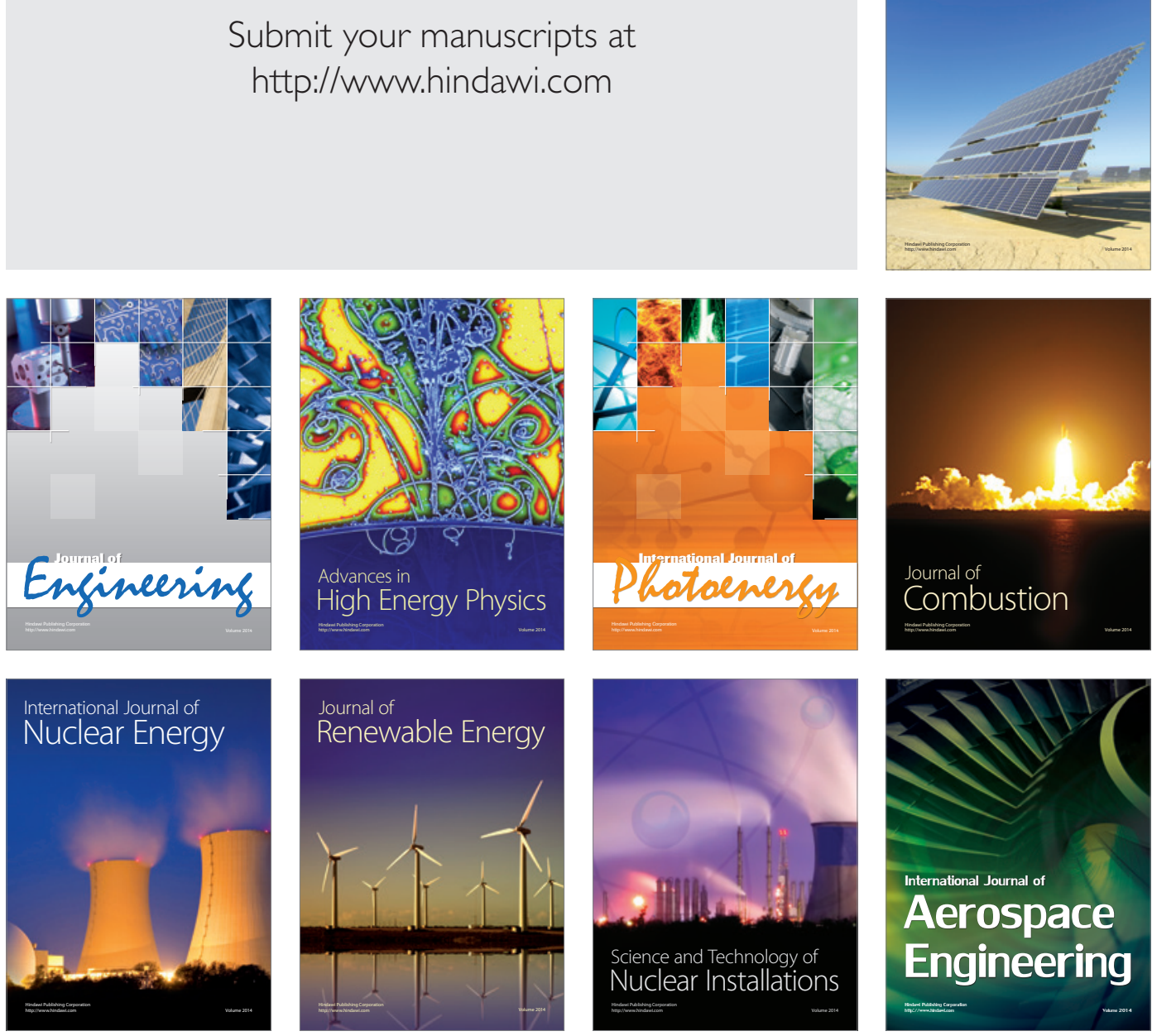